\title{
THE PROBLEM OF BELIEF IN LITERATURE.
}

The writing of imaginative literature is a creative activity and a function of what Coleridge calls the "Esemplastiv Imagination"; a unifying process, creating a synthesis out of the welter of sense perceptions, associations, ideas, attitudes, volitions, and imaginative experiences of the human mind. As Shakespeare says, the poet gives to "airy nothing", in the sense of vague and confused feelings and thoughts, "a local habitation and a name".

In the same sense, the understanding and the enjoyment of literature require a re-creative activity by the reader. By this I do not subscribe to an extreme relativistic theory which considers the literary work merely as a stimulus to stimulate the various readers to construct their own private versions of it. A work of art is, after all, autonomous, and should be considered as such. But no matter how much we respect the autonomy of the poem, that is, its right to an objective, and not merely a subjective or relative, existence, the fact remains that it does not "exist" for the reader who has not succeeded in understanding and in appreciating it. By understanding I mean grasping the paraphrasable content, whereas appreciation implies judgment of value, favourable or adverse.

This appreciation requires an imaginative contribution which consists of re-creating the poem in the reader's mind, and the greater the literature, the greater the intellectual and emotional effort required to effect this re-creation. It is a matter of "Einfühlung", empathy, which Pope has described as ,reading in the same spirit as that in which the author wrote".

Training in literary appreciation is accordingly necessary because, no matter what imaginative endowment or natural sensibility the reader might possess, he has to acquire the art of appreciation by patient application, and he has to combine practice in reading with experience of life. When a work of art is rejected as bad by a competent critic, it implies that he has not found it to be worth the imaginative contribution which as a result of practice plus intuitive empathy he is able to give to an object which is worth while.

No literature can avoid in some way or other expressing or betraying the writer's attitude and opinions. And there is no reason why it should be otherwise. The very greatness and the value of literature derive from the fact that it deals with human affairs, cither directly or as a projection of human attributes into the external world. In this sense Matthew Arnold was right in his definition of literature as "Criticism of Life". 
The question now is: to what extent are we, as readers, in this re-creative responsiveness, in our judgment of value, affected by the opinions and the attitude to life implicitly of explicitly embodied in the literary work? Does, and should, disagreement with thee writer's point of view adversely determine our judgment of the value of the work, and conversely, does agreement with that view facilitate responsiveness?

There is little difficulty with the admittedly fanciful element in what we might call "fairy-tale" literature-Grimm's "Tales", "Alice in Wonderland", Shakespeare's "Midsummer Night's Dream". Here the supernatural element is accepted as mere fancy by what Coleridge has called the "willing suspension of disbelief". The problem lies with literature which assumes that it will be taken seriously as far as direct or indirect expression of belief or attitude is concerned.

The eminent Cambridge critic, I. A. Richards, now of Harvard, has given considerable attention to this problem of belief and the allied question of poetic truth. In order to understand his view on this point, we have to see it in relation to two aspects of hs criticism.

First, the general aim of his criticism. He has felt himself called upon, in our scientific age with its sceptical attitude to spiritual matters, to restate and justify the claims of imaginative literature. His problem has accordingly been to justify the poetic use of language. Hence all his criticism centres round the question of "Meaning". What is scientific "meaning", and what is poetic "meaning"? This is the ever-recurring question in his critical writings.

Secondly, his philosophy of language. He says that there are two uses of language: at one pole the language of pure notation, such as mathematical symbols, where factual or logical communication is the main consideration. This is the language of "scientific" communication. To be distinguished from this, he postulates the emotive or evocative use of language, where the intention is, not factual or reasoned communication, but to stimulate to action, to evoke feelings or attitudes-such as, on a lower level, advertisements and propaganda, and, on a higher plane, religion and imaginative literature.

His theory of belief fits into this general theory of language. He maintains that in scientific matters, where the aim is factual or hypothetical communication, we are called upon to accept or reject the facts or hypotheses intellectually; ; that is, the idea of in intellectual belief or disbelief, implying intellectual or logical analysis. In the emotive use of language we have emotional acceptance or rejection, independent of intellectual scrunity. 
This, then, is how he tries to solve the problem of belief. Imaginative literature, accordingly, is satisfying because only emotional belief is necessary, intellectual or logical belief being not required or invited.

Now Richards's theory is useful as an elementary distinction, especially for beginners, but it breaks down under more profound scrutiny, for the simple reason that it over-simplifies what is a very complex phenomenon. In the various forms of "emotive" language we cannot separate the functions of the intellect and the emotions. The highest forms of religion and the finest poetry can stand the test of the intellect, and even in lower forms of emotive language, such as the propaganda swallowed by a gullible public, some kind of intellectual element is present. We cannot divorce intellectual assent and emotional belief in such an over-simple way.

Strangely, T. S. Eliot, foremost poet and a particularly sensitive critic, also slips up on this matter of belief in literature. Writing, in his later criticism, with a thesis at the back of his mind-the justification of his conversion to Roman Catholicism--he says of Shelley: "The reason why I was intoxicated by Shelley at the age of eleven, and now find him almost unreadable, is not so much that I accepted his ideas and have since come to reject them, as that at that age the question did not arise ... I can only regret that Shelley did not live to put his poetic gifts, which were of the first order, at the service of more tenable beliefs . . ."

Mr. Eliot misses the point. It is not the "untenableness' of Shelley's beliefs, it is the lack of thought and profundity. The trouble with Shelley is that he is essentially a poet for the immature mind in the "Sturm and Drang" phase of life-by reason of his exuberance, his wild imaginative flights, his irresponsible use of language. Unfortunately, his manner, his cocksure tone, invites logical scrunity, much to his detriment. It throws out a challenge to examine his thought, as, for instance, we do in the perfect fusion of thought and emotion in Shakespeare, whose manner Shelley so obviously imitates. And he fares very badly under such an examination.

This is what Eliot intuitively objects to: not the wrongness of Shelley's thought, but his lack of it. (This crops up again when we consider the problem of sincerity. Shelley's weakness is that it is not sincere thought; it is a pose.) Eliot is right in his dislike of Shelley, but he is wrong in his theoretical justification of his aversion.

How, then, are we to solve the problem? Must we be satisilied with a purely relativistic, subjective theory of art?

I think we can come to a satisfactory working conclusion, if, starting with literature ue know, we ask ourselves, in a simple, practical way, what the function of the writer really is. 
In connection with this matter of poetic belief, I conducted a simple experiment in criticism with a class of third-year students. Starting with "Cry, the Beloved Country", which raises the highly contentious question of the Native problem in South Africa, and in the discussion referring to such views as Shaw's Life Force, Butler's attack on religion, Milton's Puritanism, Dante's Catholicism, Auden's communism, we tried inductively to answer the question: What do we expect the writer to do in this matter of belief?

l an here giving the suggestions, with the replies offered by students.

(1) The book expounds a wrong political theory, and has therefore done South Africa a lot of harm overseas.

Reply: That is altogether too crude a view. The reader cannot require the novel to conform to his own brand of politics. And, after all, who are we to judge?

(2) The book should give a reliable account of the social milieu which forms the background.

Reply: The writer is not a social researcher, who has to collect and interpret factual data.

(3) The writer is writing about the plight of the detribalised Natives. He should, then, make out a convincing case for them.

Reply: The writer is not an advocate, who has to make out a case for his clients.

(4) The writer should be constructive in the sense of offering a practical solution.

Reply: The writer is not a politician or a social reformer who has to find or profess to find "solutions".

Finally, the following view was endorsed as most generally acceptable. I an not offering it here as a complete poetic theory, but merely as a practical point of view which has proved of value to the students.

The writer is under no obligation to conform to our moral, political, or religious views. The test is rather whether he succeeds in presenting, as he has experienced it, some aspect of the human situation, directly or projected.

Before the Fall, Adain and Eve's literature would have been unmixed songs of praise, as in the early part of "Paradise Lost": 
“ for in their looks divine

The image of their glorious Maker shone,

Truth, wisdom, sanctitude, severe and pure".

Subsequently, after

"Man's first disobedience. which

Brought death into the world, and all our woe",

the human consciousness has forever been hovering between the opposite poles of Good and Evil. As Mrs. Gaskell said of Charlotte Brontë, every human soul is a "battle-field", a scene of conflict. In this great human drama, with its despair and its aspirations, its humour and its poignant tragedies, we are all participants. Both the writer and the reader see as in a glass, darkly.

And what the reader is entitled to demand is that the writer should give, according to the light he has, an honest, sincere version of what he has experienced of life and its perplexities.

"So runs my dream; ; but what am I?

An infant crying in the night;

An infant crying for the light;

And with no language but a cry."

Humility, sincerity and human sympathy are the requisites for a good reader, as well as for a good writer.

This, then, is how poetic truth is accepted - not as factual information, not as logical verifiability, not as conforming to our view of life, not by philosophic reasoning, but by intuitive (Croce), imaginative (Coleridge), appreciative (Leavis) "Einfühlung" of the sincerity of the presentment of the human situation as experienced, selected, and organised by the imagination of the writer.

I. J. FOURIE. 